\title{
KESENJANGAN KONSEP DAN PENERAPAN GAYA MODERN MINIMALIS PADA BANGUNAN RUMAH TINGGAL
}

\author{
Erlina Laksmiani Wahjutami* \\ Jurusan Teknik Arsitektur Fakultas Teknik Universitas Merdeka Malang \\ *erlina @unmer.ac.id
}

\begin{abstract}
ABSTRAK
Gaya Arsitektur Modern Minimalis sedang menjadi trend dalam mengisi kekayaan khasanah arsitektur di Indonesia. Banyak pengembang yang menawarkan gaya ini pada rumah-rumah tinggal yang mereka bangun. Dalam penawarannya mereka menyebutkan gaya Modern MINIMALIS ini sebagai bagian dari pemasaran mereka. Tetapi apabila dikaji lebih dalam, unsur-unsur dan prinsip-prinsip perancangan yang mereka pakai sebagai konsep Modern MINIMALIS tersebut kurang atau bahkan tidak mencerminkan gaya tersebut apabila ditelusur dari unsur-unsur dan prinsip-prinsip perancangan yang diambil dari arsitek-arsitek Modernist pencetusnya. Arsitek-arsitek Modernist yang mewakili pemikiran gaya ini diantaranya adalah: Mies van der Rohe, Frank Lloyd Wright, Le Corbusier, Gerrit Rietveld, dan masih banyak lagi lainnya. Mereka secara umum mencanangkan Arsitektur Modern sebagai dasar berpikir merancangnya walaupun mereka mempunyai kekhasan konsep masing-masing yang berbeda. Gaya arsitektural Minimalis yang ditawarkan pengembang - terutama pada pemecahan fasadenya bisa jadi merupakan persepsi dari masing-masing arsiteknya atau hanya merupakan salah satu strategi pemasarannya saja. Denah tidak menjadi bagian dari bahan pertimbangan konsep MINIMALIS tersebut, Hal ini terlihat dari penyelesaian denah yang standar, tidak diselesaikan dengan pemikiran khusus. Pada akhirnya, pemilihan istilah Modern MINIMALIS untuk gaya perancangan bangunan yang banyak ditawarkan pengembang tersebut lebih pada penyelesaian fasadenya yang minimal, tidak mendalam sampai pada tataran filosofi seperti yang yang telah digariskan oleh para arsitek pencetusnya.
\end{abstract}

Kata Kunci - Modern Minimalis, konsep, rumah tinggal

\section{PENDAHULUAN}

Akhir-akhir ini banyak pengembang menawarkan rumah tinggal dengan gaya yang mereka sebut sebagai Modern Minimalis. Sebuah gaya yang pernah menjadi trend pada masa berkembangnya Arsitektur Modern pada masa jayanya International Style. Permasalahannya adalah apa yang disebut dengan gaya Modern Minimalis tersebut kurang sesuai dengan konsep yang telah dicetuskan oleh pemrakarsanya, yaitu para tokoh-tokoh arsitek Aliran Modern. Telah terjadi semacam kesenjangan antara konsep aslinya dengan terapan gaya arsitektural yang diinginkan pengembang. Pada penelitian ini, terlebih dahulu dibuat pemerian secara fisik terhadap fasade bangunan rumah tinggal dengan unsur-unsur dan prinsip-prinsip perancangan yang dicanangkan oleh para arsitek Modernist.

\section{TINJAUAN PUSTAKA}

\section{Arsitektur Modern}

Gaya arsitektur sebelum munculnya arsitektur modern diwaranai dengan pernak-pernik ornamen yang meramaikan fasade bangunannya. Dengan adanya 
revolusi industri yang memicu lahirnya arsitektur Modern, merubah sama sekali gaya perwajahan yang telah ada sebelumnya ini.

Tujuan gerakan Arsitektur Modern adalah untuk menciptakan sebuah "gaya murni" yang mengekspresikan zamannya. Faktor kedua yang mempengaruhi munculnya gagasan Arsitektur Modern adalah Revolusi Industri. Revolusi Industri telah menyediakan metode konstruksi baru yang memungkinkan solusi baru, menciptakan dukungan dan masalah-masalah baru, dan mendorong terciptanya bentuk-bentuk baru.

Adolf Loos pada tahun 1907 menyatakan, "Kita telah memiliki gaya abad ini sebagai evolusi budaya, yaitu membuang ornamen dari obyek-obyek utilitarian. Ornamen hanyalah pemborosan tenaga kerja dan kesehatan."

Menurut Larson (1993), penolakan ornamen didasari oleh: a) rasionalisasi sebagai prinsip industri dan efisiensi ekonomi dan b) penolakan ornamen serta pemurnian bentuk berkonotasi moral sebagai gerakan seni dan ideologi. Di pihak lain, pemurnian bentuk selaras dengan temuan material industri yang potensial, khususnya material kaca. Bentuk dan material membuka jalan bagi penemuan konsep ruang binaan baru (new built space). Mekanisasi dan rasionalisasi industri telah mendorong arsitek menggunakan komponen produksi massal dan standardisasi.

Masa Arsitektur Modern Fungsionalisme (1900-1940) sangat dipengaruhi oleh aliran kubisme, sebuah aliran dalam seni lukis. Kubisme adalah aliran seni rupa yang paling revolusioner yang mula-mula berkembang di Paris antara 1907-1920-an. Pandangan terhadap alam dan seninya sangat berbeda dengan zaman klasik. Dalam seni lukis, kubisme tidak hanya membuat bentuk dan warna tetapi memasukkan dimensi waktu di dalamnya. Sudut pandang lukisan tidak dari satu sisi, namun dari berbagai sudut pandang, bahkan terhadap sisi yang semestinya tidak terlihat. Prinsip kubisme menonjolkan aspek ruang dan waktu. Kesatuan ruang dan waktu menjadi pola pikir dan konsep seni dalam gerakan kubisme ini. Konsep keindahan mendasarkan pada kesederhanaan, keselarasan dan keseimbangan seperti pada lukisan Piet Mondrian yang hanya terdiri dari garis-garis dan blok-blok warna, menjadi inspirasi kesederhanaaan dan komposisi bidang pada bangunan. Dalam suatu bentuk perspektif, unsur ruang yang terdiri dari tiga dimensi, oleh para pelukis Cubism ditambah satu unsur lagi dimensi keempat, yaitu waktu.

Pengaruh aliran Cubism dalam arsitektur tidak secara langsung dan bersamaan, dalam lukisan mulai berlangsung antara tahun 1910 hingga 1914, Cubism dalam arsitektur barulah muncul sejak tahun 1917 hingga 1920. Pada kenyataannya, arsitektur Cubism diciptakan mula pertama oleh para arsitek antara lain: Gerrit Rietveld (1888-1964) dari Belanda untuk rumah tinggal Schroder (1924) di Utrecht. Bangunan pertama beraliran Cubism di Jerman adalah kompleks gedung Bauhaus di Dessau (1925-1926), rancangan Walter Gropius (1883-1969). Antara tahun 1927-1929 arsitek Amerika Richard Neutra (1892-1970) merancang Lovell House (1927-1929) di Los Angeles dan di Perancis pada tahun 1928 Le Corbusier merancang Villa Savoye dekat Paris dengan gaya dan bentuk Cubism. Tokoh aliran Cubism lainnya yaitu Ludwig Mies van der Rohe (1886-1969) dari Jerman dengan Paviliun Jerman dalam Pameran Internasional di Barcelona Spanyol (1929), Hugo Alvar Henrik Aalto (1898-1976) dari Finlandia dengan karyanya antara lain Tuberculosis Sanatorium di Paimio Finlandia (1929-1933). 
Dalam bentuk apa karya-karya tersebut mendapat pengaruh dari seni lukis Cubism? Terdapat tiga elemen utama dalam arsitektur yaitu material atau bahan, ruang dan pencahayaan. Dalam arsitektur klasiktradisional Eropa, material adalah aspek utama yang memberikan kekuatan dalam konstruksi. Ruang pada arsitektur masa itu selalu terletak dalam dinding tebal, di mana hanya sedikit cahaya masuk. Sejak Cubism para ahli sejarah kesenian mencatat bahwa arsitektur bukan lagi seperti selubung, tetapi ruang menjadi aspek paling dominan dan merupakan unsur utama, aspek kedua pencahayaan, sedangkan material hanya menempati posisi ketiga.

Ruang terbuka dalam arsitektur Cubism merupakan realisasi dari konsep menyatunya ruang dalam dan ruang luar. Bukaan dalam lantai, dinding dan atap menjadi bagian yang penting dalam arsitektur, selain menghubungkan ruang-ruang atas-bawah dan ruangruang bersebelahan, juga sebagai unsur yang memasukkan cahaya. Ruang-ruang dalam bangunan menyatu secara berkesinambungan melaui kolomkolom, bukaan pada dinding dan bukaan pada lantai atau mezzanine dan atap datar yang digunakan untuk ruang terbuka di atas. Setelah dimensi ruang terbentuk, akhirnya dimensi waktu tercipta sekaligus oleh gerakan cahaya dan pergerakan manusia dalam bangunan.

Arsitek besar gerakan Arsitektur Modern yang sangat dipengaruhi oleh pemikiran kubisme adalah Le Corbusier yang berpendapat bahwa peran seni dalam arsitektur berpengaruh besar pada perkembangan Arsitektur Modern. Le Corbusier pulalah yang memperkuat dan mendorong gagasan purisme di dalam arsitektur. Menurutnya, bentuk yang paling indah terletak pada bentuk-bentuk geometri.

Gagasan ke arah purisme di dalam arsitektur dipengaruhi pula oleh pemikiran-pemikiran kelompok seni lukis abstrak. Di Belanda kelompok ini membentuk aliran arsitektur De Stijl. Dalam pandangan seni abstrak De Stijl, semua pengertian tentang obyek dihilangkan secara total, yang tersisa adalah ekspresi visual yang dibatasi oleh garis-garis lurus dan sudut-sudut persilangan garis vertikal dan horisontal. Warna yang digunakan hanya tiga warna dasar: merah, kuning dan biru, ditambah dengan warna hitam dan abu-abu.

Gagasan purisme di dalam Arsitektur Modern menemukan bentuknya yang paling radikal di tangan Mies van der Rohe. Karya-karya Mies menekankan pada fungsi, kesederhanaan, dan abstraksi seperti pemikiran kelompok De Stijl. Konsep purisme Mies diterapkan di dalam arsiitektur dengan hanya menggunakan elemen garis-garis lurus menggunakan bahan-bahan baja dan dinding penutup kaca. Konsep baru dari Mies adalah dinding partisi yang bersifat fleksibel yang dapat diatur sesuai kebutuhan. Arsitektur karya-karya Mies menunjukkan penyelesaian arsitektur yang sangat minimalis. Ia kemudian menelorkan doktrin "less is more".

Konsep ruang dan denah didasarkan pada hal-hal berikut. Pertama, kerangka struktur baja atau besi menggantikan fungsi dinding penahan. Dinding dapat direduksi menjadi membran saja. Kedua, denah interior bebas dari rangka kolom pendukung, sehingga menjadi geometri bebas. Ketiga, bukaan pada fasad berbentuk garis yang mencapai tepi atau mengitari fasad, dan bisa berbentuk kaca vertikal.

Kebutuhan, bahan, moral, dan paham baru tercermin dalam arsitektur dan seni. Implikasi dari penerapan pemikiran modernisme adalah munculnya bangunanbangunan tinggi yang didesain dengan menggunakan prinsip "arsitektur sebagai volume mengutamakan keteraturan, dan tanpa ornamen". Wujud bangunannya adalah atap datar, kotak, berwajah 
bersih, jendela memanjang, dan penggunaan komponen produksi industri. Gejala ini melampaui batas-batas negara, sehingga dianggap bersifat Internasional.

Pendapat Mangunwijaya (1995) tentang Arsitektur Modern Minimalis adalah bahwa estetika perencanaan dirajai oleh, misalnya, drama pergulatan antara unsurunsur vertikal dan horisontal, antara ruang hampa dengan gatra masif, drama tegangan antara daya berat beban daya pemikul, tegangan antara kebekuan statika dengan gelora dinamika, tegangan antara unsur-unsur simetri dengan asimetri, tegangan antara rupa yang geometris abstrak dan rupa yang organis bulat melengkung dengan rupa-rupa yang lurus abstrak. Tegangan antara daya-daya irama yang bergerak dengan lawannya, daya-daya penghambat dan sebagainya. Tegangan atau pergulatan di sini jangan disama artikan dengan "permusuhan", tetapi hendaknya dirasakan dalam suasana makna hubungan dua pola yang dwi-namun-tunggal pula, yang dialektis dan yang saling membatasi namun saling melengkapi pula; demi suatu keseimbangan yang tahan uji. Dasar estetika tersebut pada dasarnya berakar pada pengertian dan sikeap manusia Barat terhadap materi, melainkan terhadap fenomen (gejala) realita yang kita badapi dalam suasana pergulatan.

Estetika tdiaklah ditinggalkan begitu saja, akan tetapi ciri estetis mereka kebanyakan adalah estetika yang memberikan kebahagiaan rasio. Garis-garis lurus, bidang-bidang geometrik mengekspresikan penikmatan keindahan yang terjalin dalam bentukbentuk matematika. Kemurnian, kebeningan, kepolosan, seperti yang dikagumi oleh manusia Barat dalam teladan mereka, Arsitektur Jepang menjadi ideal umum dalam kurun waktu tahun 60 dan 70-an.

Kelompok E9 Architecture Writer (2007) menyarikan gaya minimalis bangunan sebagai berikut: prinsip pada gaya minimalis adalah penghematan dari segi ruang, yaitu penataan dan pembentukan ruang berdasarkan studi kebutuhan ruang atas fungsi. Penghematan dari segi cahaya, yaitu dengan cara memaksimalkan pencahayaan alami dengan membuat bukaan-bukaan cahaya yang luas dengan menggunakan dinding berbahan kaca. Penghematan dari segi massa, yaitu dengan cara meminimalkan massa bangunan.

Secara gubahan bentuk, intinya adalah memaksimalkan karakter asli bangunan dengan mengeksplorasi struktur dan bahan yang digunakan sebagai daya tarik bangunan. Bentuk bangunan cenderung simple dengan permainan bentuk geometri yang sederhana, tidak rumit dan tegas. Garis-garis pembentuk bangunan biasanya merupakan perpaduan garis horisontal dan vertikal, dan jarang menggunakan garis lengkung. Misteri bidang dan garis yang terdapat pada bangunan dijadikan sebagai daya tarik visual.

Bangunan terdiri dari komposisi bentuk-bentuk dasar Platonic solid yang sederhana dengan permainan garis dan bidang, dengan atap yang datar (konsekuensi dari bentuk geometri dasar).

\section{Tokoh-tokoh Arsitektur Modern beserta karya- karya arsitekturnya.}

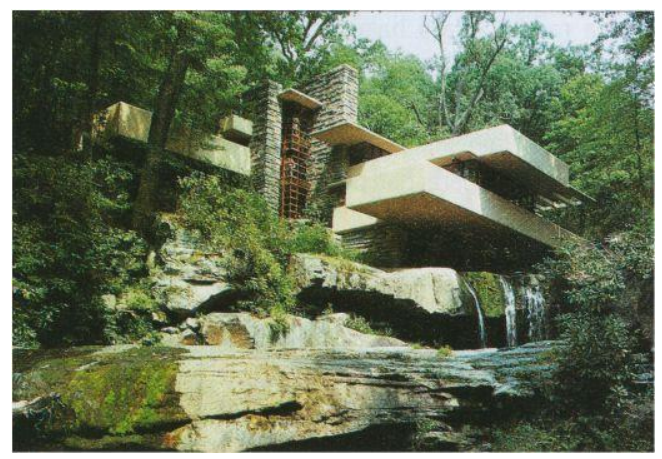

Gambar 1. Kaufmann House, Pennsylvania karya Frank. L Wright 
Kaufmann House, Pennsylvania pada gambar 1. merupakan penerapan konsep menyatu dengan alam yang sangat efektif. Ruang keluarga dibuat menjorok dan melayang di atas air terjun dari aliran sungai di bukit kecil bernama Bear Run. Keadaan demikian membuat bangunan ini dinamakan The Falling Water, di mana suara gemericik air tidak pernah behenti menjadi bagian dari pemasukan unsur alam ke dalam ruang-ruang sebagai "musik alami". Rumah terdiri dari tiga lantai, masing-masing dinding balustrade dan lantainya membentuk blok dan bidang-bidang horisontal dari beton bertulang melayang satu di atas yang lainnya, dan salah satu sisinya masuk ke dalam tebing karang. Unsur vertikal dibentuk oleh dindingdinding dilapis oleh pecahan batu karang, menyatu dengan lingkungan yang juga terdiri dari tebing karang, menjadi tumpuan dari bidang-bidang datar melayang tersebut di atas.

Pada prinsipnya konsep organisme Wright adalah bahwa bangunan adalah mesin untuk kegiatan tertentu. Hal yang berbeda secara prinsip antara karya Wright dengan arsitektur modern Eropa pada umumnya, terlihat dalam merancang dinding ia cenderung membuat bidang permukaannya tidak halus bersih ataupun diberi warna dasar (merah, kuning, biru) seperti gaya De Stijl, tetapi mempunyai tekstur dan warna asli dari materialnya.

Berbeda lagi dengan arsitek yang satu ini, Le Corbusier pada tahun1926, mempublikasikan konsepkonsep dalam perancangan arsitektural dari karyakaryanya yang telah dibuatnya berjudul Lima Butir dari Suatu Arsitektur Baru (Les points d'une architecture nouvelle). Kelima butir tersebut adalah: (1) Kolomkolom mengangkat bangunan lepas dari tanah. (2) Perencanaan bebas, memisahkan beban yang disangga kolom dari dinding-dinding pemisah ruang, (3) Wajah atau tampak juga bebas dari bidang-bidang dan kolom vertikal, (4) Jendela dan pintu sorong (sliding window) panjang horisontal (fentere en longeure), (5) Atap datar digunakan untuk taman atau teras, seperti halaman yang menutup rumah.

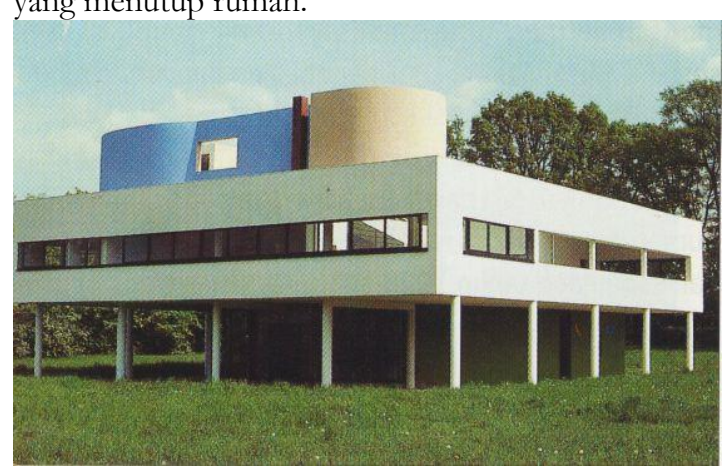

Gambar 2. Villa Savoye karya Le Corbusier

Arsitektur Villa Savoye pada gambar 2. merupakan penerapan semua konsep arsitektural Le Corbusier termasuk Cubism, Purism, bentuk, pencahayaan dan terutama konsep Les points d'une architecture nouvelle. Villa Savoye berdenah segi empat, dua lantai berkesan seperti kotak putih melebar horisontal disangga oleh kolom-kolom, di tengah halaman luas. Dindingdinding lantai dasar, pintu dan jendela berada di belakang kolom-kolom berwarna gelap, kontras dengan bidang putih di atasnya, di bagian belakang dindingnya melengkung karena denahnya yang setengah lingkaran. Adanya jarak antara kolom-kolom dan dinding yang gelap tersebut, membuat bagian di atas kolom terkesan ringan seolah-olah hanya disangga oleh kolom-kolom silindris relatif sangat kecil. Ramp dan tangga menyatukan ruang bawah dan di atasnya yang satu melayang ringan, lainnya melingkar spiral mengekspresikan seni plastis dan teknologi beton bertulang.

Ciri karya arsitektur Mies van der Rohe adalah garisgaris lurus, vertikal, tegak lurus satu dengan yang lain, 
sangat menekankan pada fungsi, sederhana dan abstrak seperti halnya arsitek dalam kelompok De Stijl. Rancangan pencakar langitnya berbentuk garisgaris vertikal ke atas sangat tinggi. Terlihat di sini penerapan konsep "penyelesaian yang minimal" dari bangunan rangka baja tinggi, membentuk pencakar langit, kaya akan pantulan dan permukaan transparan dari kaca memberikan kesan seperti monumen kristal, selain juga mengekspresikan perkantoran modern. Konsep kesederhanaan dan ungkapan kemurniannya (purism) dalam arti tidak ada unsur yang tidak berfungsi dalam bangunan.

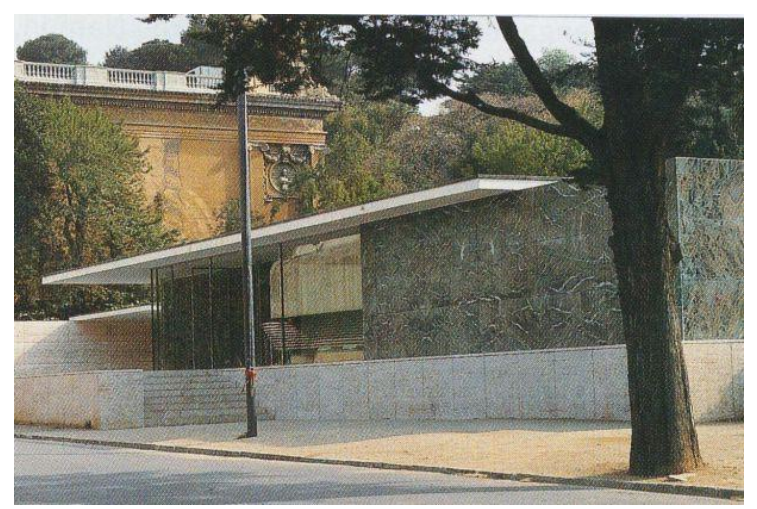

Gambar 3. Paviliun, Jerman, karya Mies van der Rohe

Kesederhanaan, kemurnian dan kesatuan ruang luardalam yang menjadi cirinya terlihat pada karyanya Paviliun Jerman dalam Pameran Internasional di Barcelona, Spanyol. Semua dinding, jendela dan pintu utuh dari atas sampai bawah membentuk bidangbidang vertikal. Atap datar dari beton bertulang berwarna kontras dengan dinding dalam komposisi keseluruhan menjadi unsur horisontal, seolah melayang ringan di atas dinding kaca dan marmer. Selain itu kolam di dalam dengan karakter dan warna air, juga menjadi elemen bidang horisontal dalam komposisi ini.
Gambar 4 adalah rumah di Utrecht, negeri Belanda, 1924. Arsitek: G.Th. Rietveld yang memiliki omposisi selaras antara garis, bidang dan prisma, keterbukaan dan ketertutupan, horisontal dan vertikal, dinding tembus cahaya

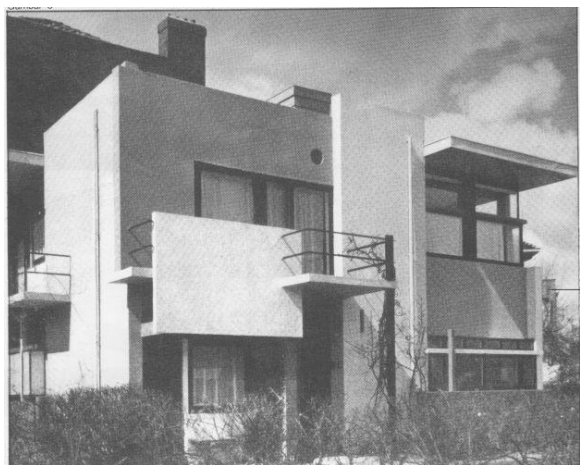

Gambar 4. Rumah Harmoni Geometrik karya G. Th. Rietveld.

\section{Kasus Penerapan Konsep Hunian Modern Minimalis di Kota Malang}

Di bawah ini adalah sampel penelitian yang mewakili pengembang-pengembang yang ada di kota Malang yang mengadopsi konsep hunian Modern MINIMALIS sebagai dasar peran-cangannya. Yang diamati terutama adalah pada fasadenya/ perwajahannya sebagai kajian yang pertama kali diapresiasi di arsitektur. Denah rata-rata merupakan standar pengembang umum sehingga tidak masuk dalam kajian yang lebih dalam.

De Bougenville Park (gambar 5.) mengangkat hunian berkonsep Modern Minimalis. Town House Taman Sigura-gura Indah(gambar 6.) mengemukakan konsep perumahan Modern Minimalis dengan menyatukan alam dan menjadikan hunian untuk keluarga hamonis dengan lingkungan bersih dan aman. Ijen Nirwana. Design (gambar 7.) mengemukakan konsep modern \& exclusive. Nirwana Sulfat Residence (gambar 8.) menyatakan hunian dengan konsep minimalis style 
dimana kemewahan gaya hidup modern dan keindahan alam berpadu sempurna. Delta Dieng Regency (gambar 9.) mengangkat konsep minimalis. Singhasari Residence (gambar 10.) mengangkat konsep hunian dengan sentuhan etnik yang dipadukan dengan unsur modern-minimalis.

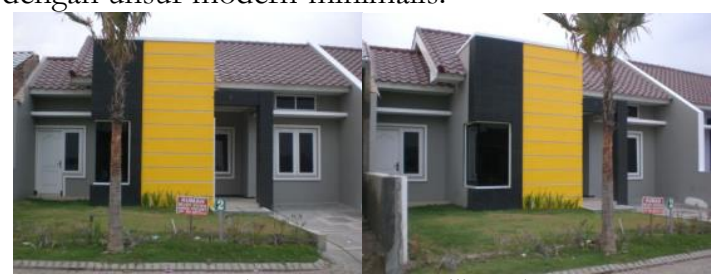

Gambar 5. De Bougenville Park

Hunian berkonsep Modern Minimalis

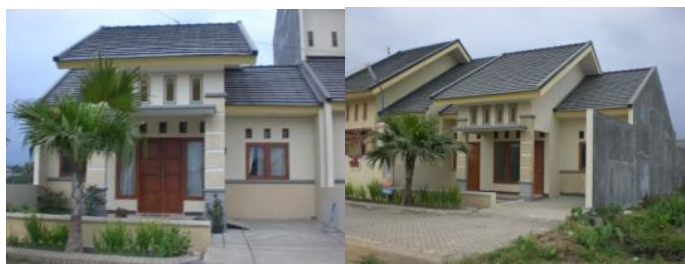

Gambar 6. Town House Taman Sigura-gura Indah.
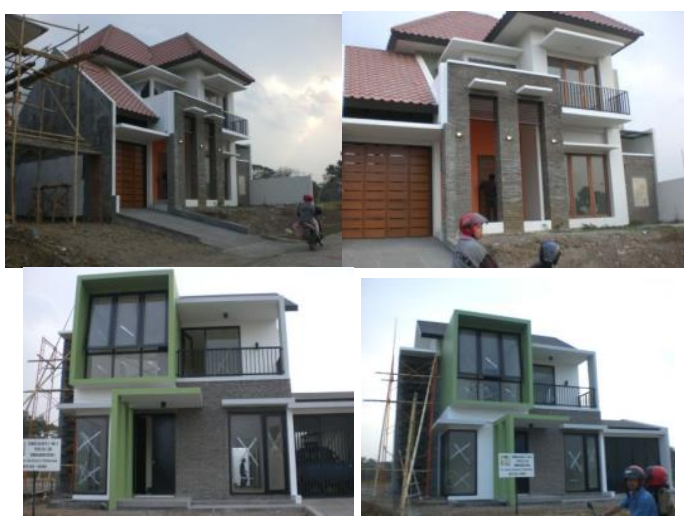

Gambar 7. Ijen Nirwana. Design modern \& exclusive

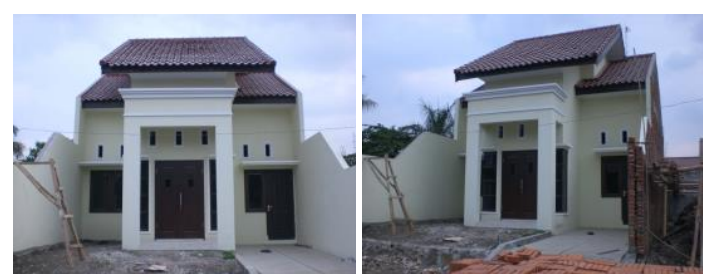

Gambar 8. Nirwana Sulfat Residence.

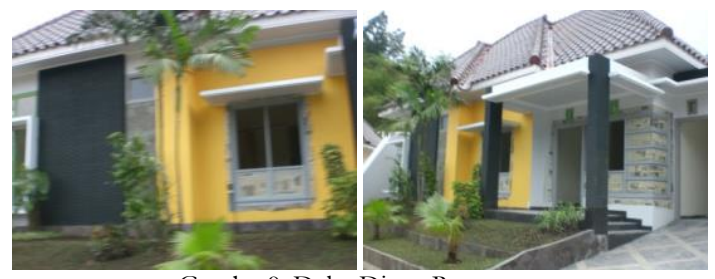

Gambar9. Delta Dieng Regency.

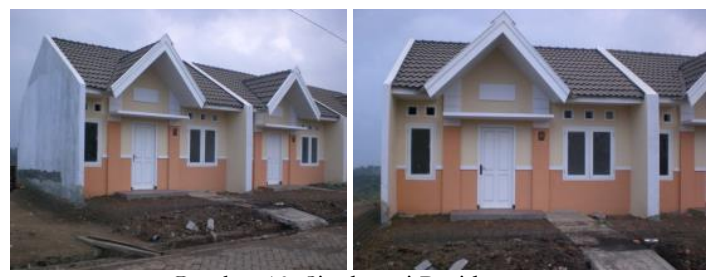

Gambar 10. Singhasari Residence.

\section{HASIL PENELITIAN DAN PEMBAHASAN}

Unsur-unsur dan prinsip-prinsip peran-cangan yang telah diuraikan tersebut menjadi tolok ukur untuk melihat bangunan rumah tinggal di atas. Dari tujuh kasus bangunan yang memakai konsep hunian Modern Minimalis tersebut, hampir semua tidak menampilkan permainan geometris maupun unsurunsur garis, bidang dan ruang yang cukup berarti.

Pengembang De Bougenville Park mencoba "bermain" dengan mengekspos sebuah bidang yang cukup dominan dengan menampilkan salah satu warna Mondrian, yaitu kuning yang dipadu dengan abu-abu untuk memperlihatkan konsep Modern MINIMALIS 
mereka. Hal yang hampir sama dilakukan oleh pengembang Delta Dieng Regency.

Sedangkan pengembang Town House Taman Sigura-gura Indah berusaha menampilkan bentuk-bentuk geometris pada jendela dan bouvenlichtnya yang memanjang tanpa adanya permainan warna-warna dasar pada dindingnya. Hampir sama halnya dengan pengembang Nirwana Sulfat Residence, bahkan bentuk geometris yang diperlihatkan lebih sederhana lagi.

Pengembang Singhasari Residence bahkan berani mengatakan bahwa gaya arsitektur mereka adalah sentuhan etnik yang dipadukan dengan unsur modern-minimalis, sebuah gaya eklektis yang bahkan hampir tidak terlihat sama sekali perpaduan antara etnik dan modern minimalisnya.

Yang mencoba lebih konsisten dengan konsep hunian yang mereka usung adalah pada pengembang Ijen Nirwana di mana banyak unsur-unsur Modern MINIMALIS yang coba mereka tampilkan antara lain: adanya permainan garis, bidang dan ruang walaupun tidak diselesaikan dengan tampilan warna-warna dasar. Terlihat permainan garis horisontal-vetikal dan bidang yang berpengaruh pada pencahayaan sehingga terkesan ada usaha permainan keterbukaan dan ketertutupan.

Rata-rata denah yang ditawarkan hampir sama, yaitu standar yang biasa dipakai pengembang, sehingga bisa dipastikan hampir tidak ada perjalanan waktu di dalam ruang yang menjadi ciri denah pada arsitektur Modern.

Sebagai bahan perenungan, ada kasus yang cukup menarik di mana pada kenyataannya konsep murni dari bentuk Arsitektur Modern Minimalis ini kurang sesuai untuk diterapkan di daerah Tropis. Sebuah rumah tinggal yang mencoba menampilkan seutuhnya gaya arsitektur Modern MINIMALIS dengan konsekuensi atap datar, pada akhirnya mengubah atapnya menjadi miring walaupun dengan wajah yang minimalis untuk menyesuaikan dengan iklim demi kenyamanan pemakai bangunan.

Demikian halnya dengan arsitektur Modern MINIMALIS yang ditawarkan oleh para pengembang, apakah konsep hunian mereka sudah merupakan adopsi konsep yang sudah berupaya bersahabat dengan iklim?

\section{KESIMPULAN}

- Melihat arsitektur sebenarnya tidak bisa hanya dari bentuk perwajahan semata tetapi sampai dengan konsep ruang yang ada di dalamnya. Tetapi inilah yang menjadi batasan pada penelitian ini.

- Penerapan gaya arsitektur pada bangunan hunian kurang begitu menampilkan komposisi garis dan bidang, ruang, namun telah berupaya memasukkan unsur cahaya sebanyak-banyaknya untuk penerangan alami

- Warna tampilan gaya Mondrian yang melengkapi gaya Arsitektur Minimalis kurang tegas diterapkan. Biasanya yang ada hanyalah satu warna dasar dengan latar belakang warna abuabu.

- Aliran Kubisme, sebuah aliran seni lukis yang juga mempengaruhi gaya arsitektur pada masa itu, dimana selain unsur tiga dimensional juga memasukkan dimensi waktu, tidak menjadi pertimbangan dalam perancangan. Sequence tidak menjadi hal yang penting.

- Kecuali pada pengembang "Ijen Nirwana", pengembang lain merancang fasade bangunan yang terjadi lebih karena tuntutan fungsi rumah tinggal sederhana yang dikembangkan atas dasar kebutuhan ruang yang paling mendasar dari konsumen, dengan kata lain lebih untuk 
kepentingan ekonomis dan kemudahan pemasaran dari pihak pengembang.

\section{REFERENSI}

E9 Architecture Writer (2007) Membangun Rumah tanpa Arsitek: 17 Desain Rumah Tinggal Modern. Yogyakarta. Penerbit ANDI.

Ikhwanuddin (2005) Menggali Pemikiran Posmodernisme dalam Arsitektur. Yogyakarta. Gajah Mada University Press.

Mangunwijaya J.B. (1995) Wastu Citra. Jakarta. Gramedia Pustaka Utama.

Sumalyo, Y. (1997) Arsitektur Modern. Yogyakarta. Gajah Mada University Press

Weston Richard, (2006) Denah, Potongan dan Tampak Bangunan Penting Abad Kedua Pulub. Jakarta. Rajagrafindo Persada. 